\title{
High Temperature Strength of Cast Irons for Cylinder Heads
}

\author{
Wilson L. Guesser ${ }^{1, a^{*}}$, Carlos S. Cabezas ${ }^{2, b}$, Luis Carlos Guedes ${ }^{2, c}$, \\ André M. Zanatta ${ }^{3, d}$ \\ ${ }^{1}$ Tupy and UDESC - Rua Albano Schmidt, 3400 - 89227-901 - Joinville - SC - Brazil \\ ${ }^{2}$ Tupy - Rua Albano Schmidt, 3400 - 89227-901 - Joinville - SC - Brazil \\ ${ }^{3}$ SENAI - Rua Arno W. Döhler, 957 - 89219-510 - Joinville - SC - Brazil \\ awguesser@tupy.com.br, bcabezas@tupy.com.br, 'Iguedes@tupy.com.br, \\ andre.zanatta@sc.senai.br
}

Keywords: Hot Strength, Compacted Graphite Iron, Gray Iron, Fractography.

\begin{abstract}
Hot strength and fracture mechanisms in high quality cast irons were studied, comparing the standard gray iron Grade 300, alloyed with Mo, typically used for cylinder heads in high power engines, with other two materials: one gray iron Grade 300, obtained through graphite refinement and one compacted graphite iron, Grade 450. In these last two materials, the strength increase was obtained by changing the graphite structure, not by hardening the matrix. The experimental results with tensile tests carried out up to $500{ }^{\circ} \mathrm{C}$ show that the different strengthening mechanisms, use of Mo or modification of the graphite structure, are both efficient for increasing the strength at room temperature as well as at high temperatures. The CGI has a lower strength reduction with temperature than the gray irons, which shows the significant impact of the compacted graphite shape in reducing the notch effect. These results show the enormous potential of CGI in cylinder heads for high-performance engines.
\end{abstract}

\section{Introduction}

Many techniques have been developed aiming to reduce emissions in diesel engines, like Diesel Oxidation Catalyst (DOC), Selective Catalytic Reduction (SCR), and Exhaust Gas Recirculation (EGR). At the same time, there is a tendency to increase the power density of engines and to have compact high-output diesel designs. All those measurements bring additional requirements in diesel engines, in particular for the cylinder head, increasing the stresses and the temperature in service $[1,2]$.

The standard cast iron typically used for diesel cylinder heads is the Mo alloyed gray iron, grade 300 (UTS min $300 \mathrm{MPa}$ ). More recently, new grades of CGI have been used for cylinder heads, starting with grade 450 and in some special applications also the grade 500.

In the present work, the tensile strength up to $500^{\circ} \mathrm{C}$ of three different high quality cast irons was studied. Two of them are gray iron, both of grade 300, one alloyed with Mo and another with a refined graphite structure, and the third a CGI grade 450.

\section{Experimental Procedures}

The three different cast irons studied are presented in Table 1, two gray irons of the grade 300 (ISO 185:2005) and a CGI grade 450 (ISO 16112:2006). The first gray iron is Mo alloyed, containing the usual pearlite forming elements used for gray irons, like $\mathrm{Cr}, \mathrm{Cu}$ and $\mathrm{Sn}$. The second gray iron, also $\mathrm{Cr}-\mathrm{Cu}-\mathrm{Sn}$ alloyed, was produced with a special inoculation, aiming to increase the strength with a refined graphite and the third is a CGI 450 alloyed with pearlite forming elements like $\mathrm{Mn}, \mathrm{Cu}$ and $\mathrm{Sn}$. It can be seen in Figure 1 that all the materials tested had predominantly pearlitic matrix, typical of these high strength cast irons. Samples of gray iron were cast in $30 \mathrm{~mm}$ diameter standard bars, while the samples of CGI were produced in 1-inch Y block. The tensile tests were conducted on test pieces with $12 \mathrm{~mm}$ diameter. The tests were performed according to ISO 
6892-2:2013 in a testing machine INSTRON 8801, with a radiation-heating furnace. The maximum temperature variation along the test sample was $3^{\circ} \mathrm{C}$. The homogenization time was 30 minutes. The loading speed was $3.5 \mathrm{~mm} / \mathrm{min}$ and 5 samples for each temperature were tested.

The fracture surfaces were examined by SEM. The presence of cracks below the fracture surface were also identified, analyzing the region up to $400 \mu \mathrm{m}$ below the fracture surface. Eight metallographic fields were examined in each sample.

Table 1 - Characteristics of the tested cast irons.

\begin{tabular}{|c|c|c|c|c|c|c|c|c|}
\hline Grade & $\begin{array}{l}\text { Carbon } \\
\text { eq [\%] }\end{array}$ & $\begin{array}{c}\text { Alloying } \\
\text { elements [\%] }\end{array}$ & Matrix & Graphite $(*)$ & cell $/ \mathrm{cm}^{2}$ & $\begin{array}{c}\text { UTS } \\
{[\mathrm{MPa}]}\end{array}$ & $\begin{array}{c}\mathrm{YS} \\
{[\mathrm{MPa}]}\end{array}$ & $\mathrm{HB}$ \\
\hline $\begin{array}{l}\text { GI } 300 \\
\text { Mo }\end{array}$ & 4.0 & $\begin{array}{c}0.2 \mathrm{Cr}-0.7 \mathrm{Cu}- \\
0.04 \mathrm{Sn}-0.27 \mathrm{Mo}\end{array}$ & Pearlite & $\begin{array}{l}\text { Lamellar - } \\
\text { Form I }\end{array}$ & 452 & 318 & & 224 \\
\hline $\begin{array}{l}\text { GI } 300 \\
\text { RG }\end{array}$ & 4.0 & $\begin{array}{c}0.24 \mathrm{Cr}-0.6 \mathrm{Cu}- \\
0.06 \mathrm{Sn}\end{array}$ & Pearlite & $\begin{array}{l}\text { Lamellar - } \\
\text { Form I }\end{array}$ & 655 & 354 & & 217 \\
\hline $\begin{array}{l}\text { CGI } \\
450\end{array}$ & 4.1 & $1 \mathrm{Cu}-0.09 \mathrm{Sn}$ & $\begin{array}{c}97 \% \\
\text { Pearlite }\end{array}$ & $\begin{array}{l}\text { Vermicular- } \\
\text { Form III, with } \\
9 \% \text { nodularity }\end{array}$ & 330 & 471 & 358 & 239 \\
\hline
\end{tabular}

(*) - graphite form evaluated according to ISO 945 and nodularity according to ISO 16112.
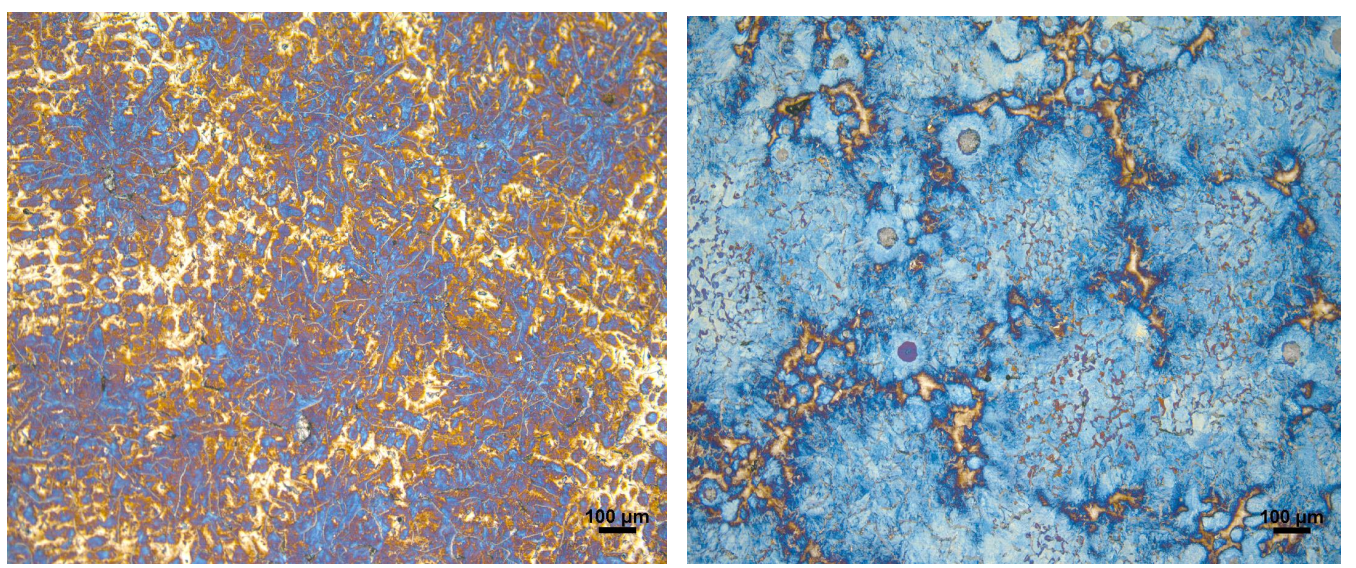

Figure 1 - Microstructure of GI 300 Mo and CGI 450 . Color etching (picric acid, $105^{\circ} \mathrm{C}, 3 \mathrm{~min}$ ).

\section{Results and Discussion}

Figure 2 shows the results of Ultimate Tensile Strength (UTS) as a function of temperature for the cast irons tested, where a typical behavior of the cast iron can be observed, with a small decrease in the strength up to $400^{\circ} \mathrm{C}$, and a steep drop in UTS above this temperature. In the CGI curve it can be observed a small increase in strength in the range of $300-400^{\circ} \mathrm{C}$. This behavior, verified in many studies for gray iron [3-6] and also for CGI [6,7], is attributed by some authors to a dynamic aging [6], but the evidences are not conclusive. It was shown that the small increase in strength could be associated with a lower graphitization rate of cementite from pearlite in this temperature range [5]. One hypothesis is the occurrence of transformations in the cementite in this temperature range, changing its stability. As the temperature increases over $450^{\circ} \mathrm{C}$, the rate of cementite decomposition increases again.

Figure 3 shows the decrease of relative strength, taking as reference the strength value at $25^{\circ} \mathrm{C}$. It is observed that the behavior of the two gray irons is very similar, showing at $450^{\circ} \mathrm{C}$ about $80 \%$ of the initial strength. CGI shows a smaller relative reduction than the gray ones, showing at $450^{\circ} \mathrm{C}$ about $87 \%$ of the initial strength. This reveals the enormous potential of using CGI in engine heads. 


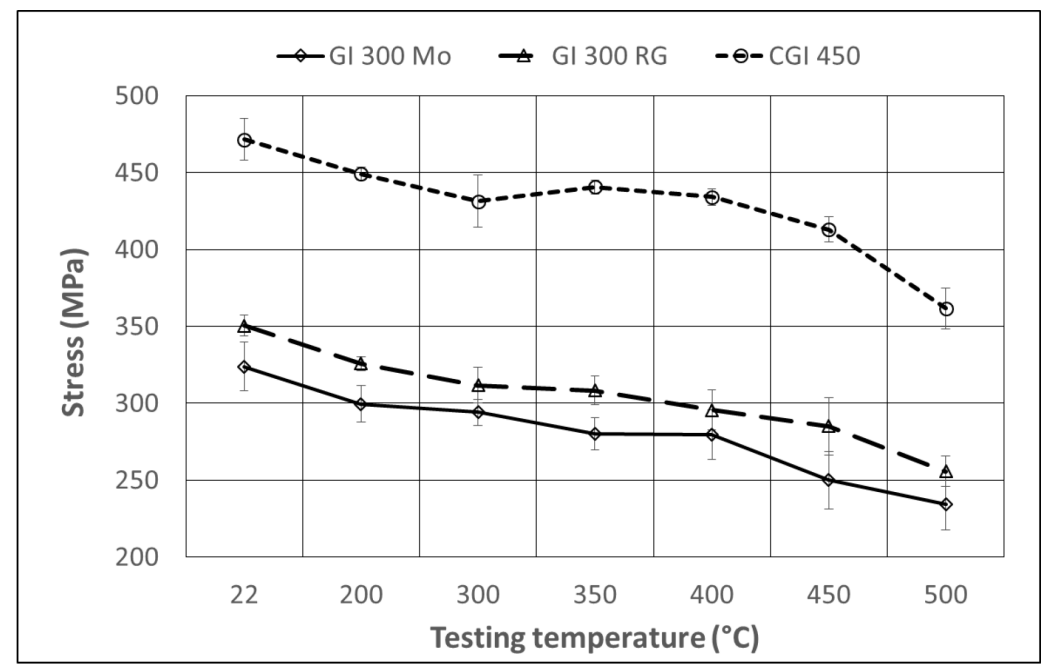

Figure 2 - Hot strength (UTS) of gray irons and CGI.

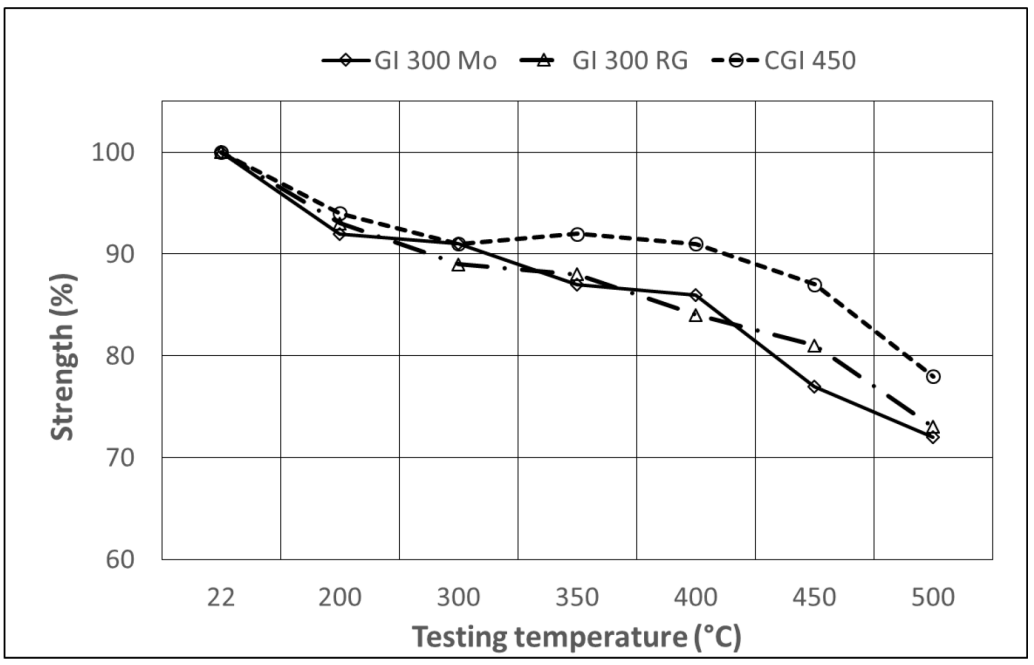

Figure 3 - Relative decrease of strength (reference value at $25^{\circ} \mathrm{C}$ ) for gray irons and CGI.

Figures 4 to 11 show fractographies of the tested materials at different temperatures. No differences were observed in the fracture surface features between the two gray irons tested. A general view of the gray iron surface fracture can be seen in the Figure 4, showing a large pearlitic matrix deformation, the plastic deformation of the matrix around particles of manganese sulfide and the separation of the matrix from the graphite plates. This separation of graphite from the matrix, through the interface, is a characteristic of the gray iron fracture. Figure 5 shows some features of the fracture of graphite/matrix interface, with the surface of the matrix revealing the graphite structure. When the graphite fracture occurs, the fracture shows the separation of plates and micro plates of the graphite structure. Figures 6 and 7 show different aspects of the graphite fracture. 


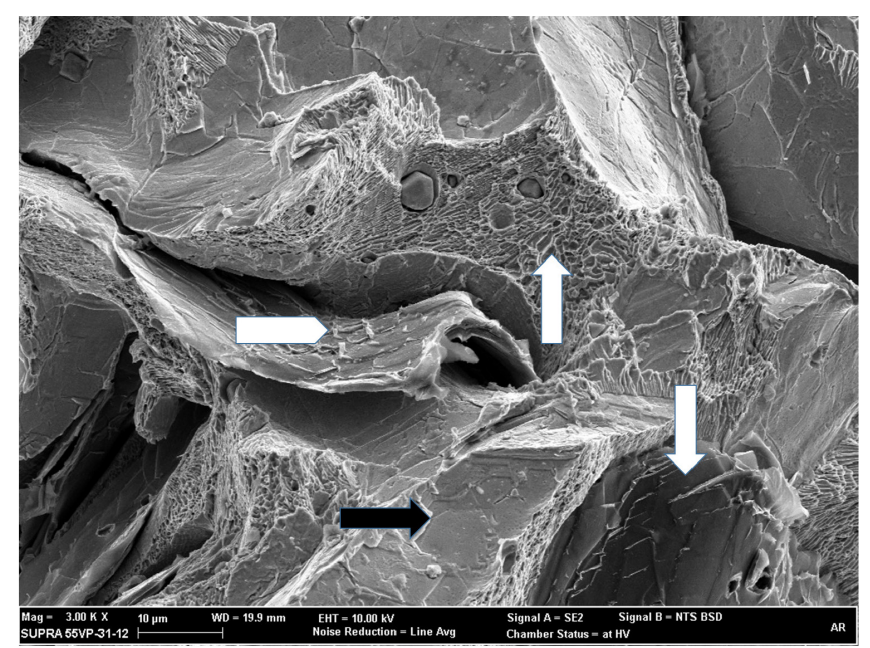

Figure 4 - Fracture of pearlite (white arrow, up), of graphite (white arrow, down), of the interface graphite/matrix (black arrow). Separation of graphite particle from the interface (white arrow, from left to right). Deformation of the matrix near graphite particles and near manganese sulfides. Ductile fracture of pearlite. (GI $\left.300 \mathrm{Mo}, 200^{\circ} \mathrm{C}\right)$.
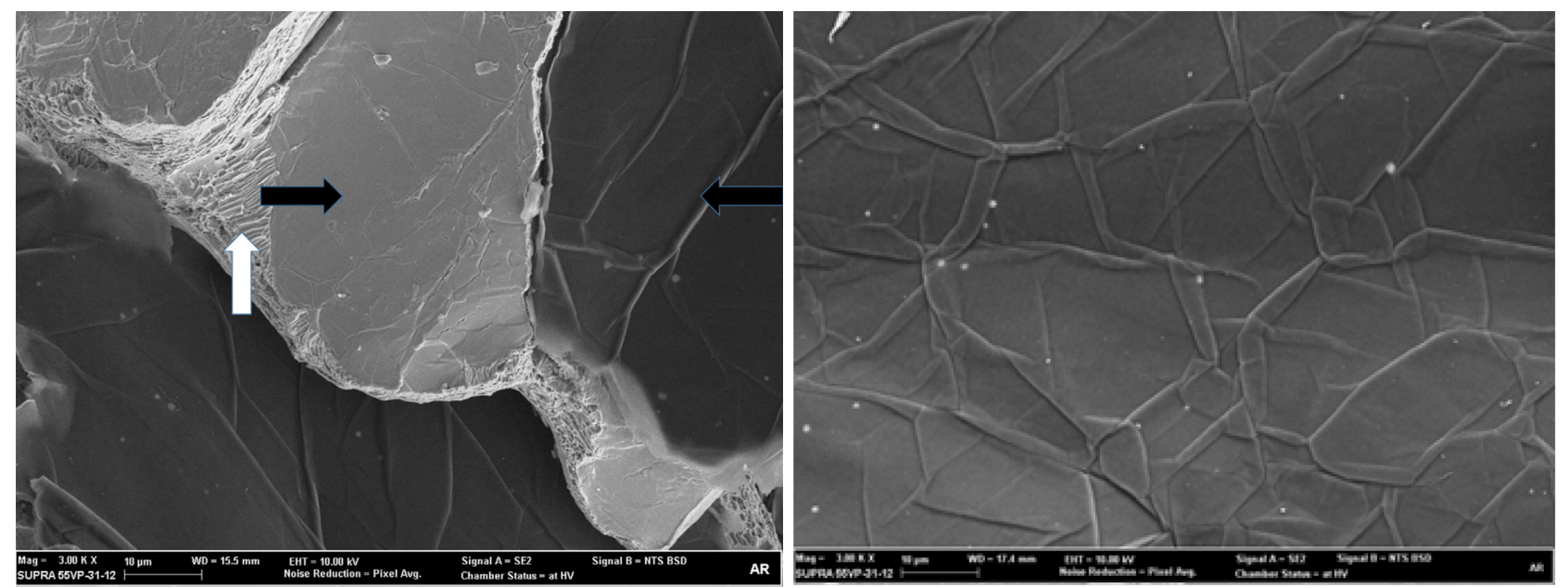

Figure $5-$ a) Preferential fracture along graphite/matrix interface, looked at the side of the matrix (black arrow, from left to right) or at the side of the graphite (black arrow, from right to left). Small areas of pearlite fracture (white arrow, up) (GI $300 \mathrm{Mo}, 350^{\circ} \mathrm{C}$ ).

b) Fracture on the graphite/matrix interface, looked at the graphite side (GI $\left.300 \mathrm{Mo}, 500^{\circ} \mathrm{C}\right)$.

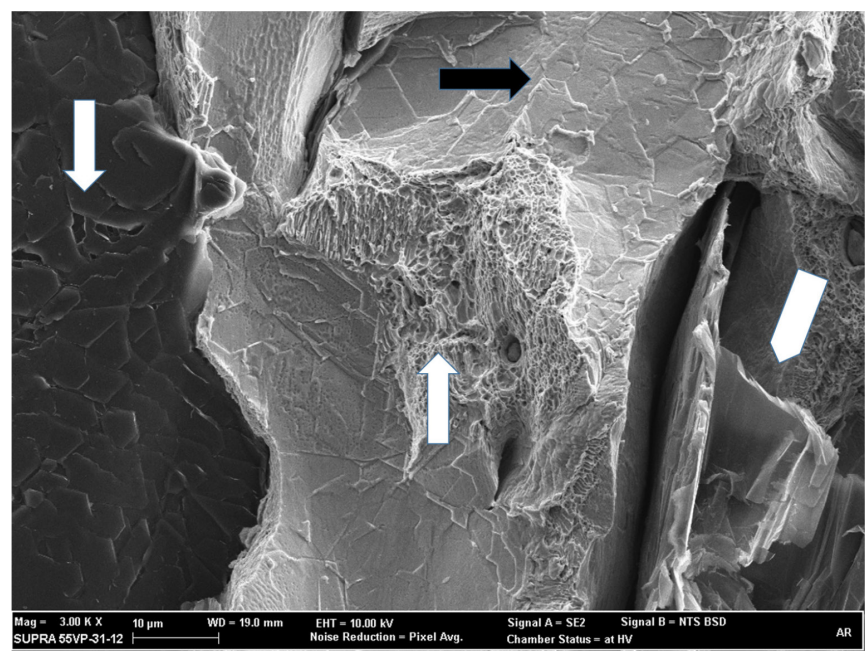

Figure 6 - Fracture of pearlite (white arrow, up), of the interface graphite/matrix (black arrow) and fracture of graphite (white arrows, down). Extensive deformation of the matrix near the graphite particles. Separation of the graphite plates (GI $300 \mathrm{RG}, 350^{\circ} \mathrm{C}$ ). 

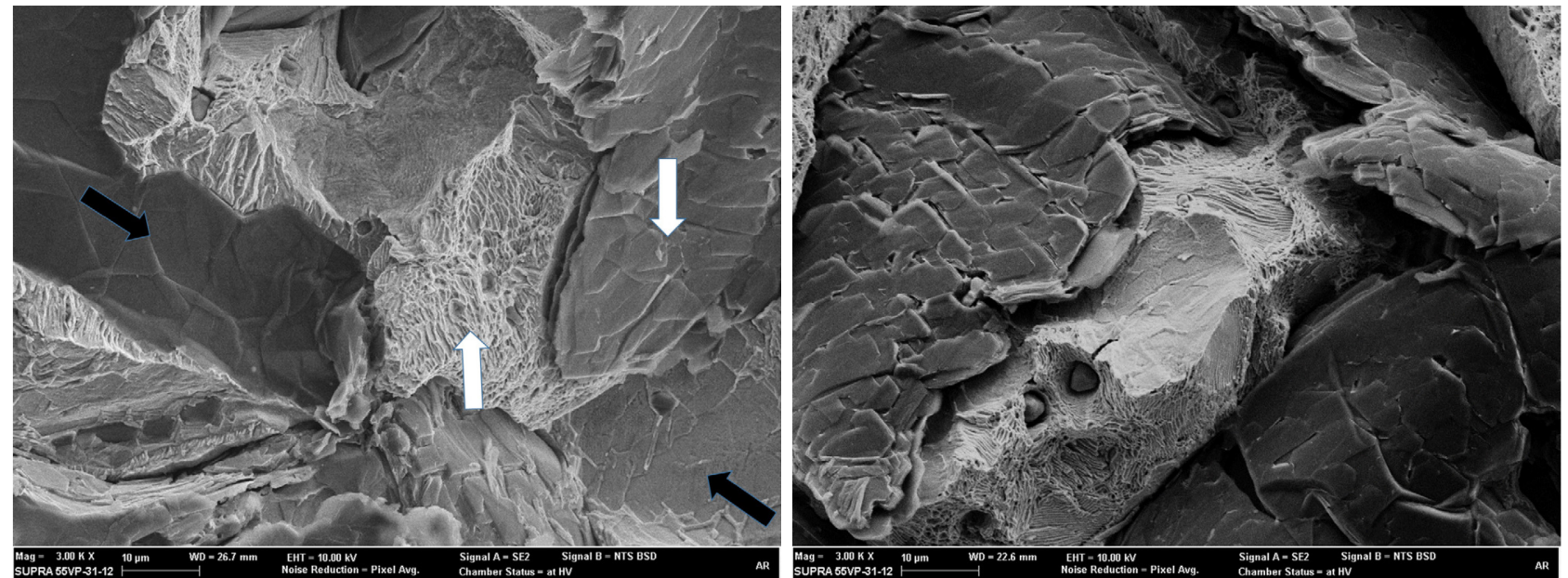

Figure $7-$ a) GI $300 \mathrm{RG}, 500^{\circ} \mathrm{C}$. Fracture on the pearlite (white arrow, up), of the graphite (white arrow, down) and of the graphite/matrix interfaces (black arrows).

b) GI $300 \mathrm{RG}, 450^{\circ} \mathrm{C}$. Fracture of graphite leading to separation of individual microplates.

Figure 8 shows an overview of the compacted graphite iron fracture: cleavage and ductile fracture of the pearlitic matrix, fracture of the graphite/matrix interface and fracture of graphite (see also Figure 9). The fracture through the graphite/matrix interface also occurs, as in gray irons, but the areas are smaller (see Figures 8 and 10). This is a result of the rougher surface of the graphite/matrix interface in CGI compared to gray iron. Thus, the fractured surface shows many areas of the graphite fracture, showing details of its microplate structure (Figure 9).

Another difference is that in CGI there are areas of cleavage in the matrix, which was not observed in gray irons. The size of the cleavage facets decreases with increasing temperature; at 200-350 ${ }^{\circ} \mathrm{C}$, cleavage facets of up to $20 \mu \mathrm{m}$ size are observed in large areas with cleavage, whereas at $450-500^{\circ} \mathrm{C}$ the cleavage facets are smaller than $10 \mu \mathrm{m}$ and the cleavage areas are also smaller. It is common to observe, at the edges of the cleavage facet, the occurrence of crack opening associated with some plastic deformation (Figure 11).

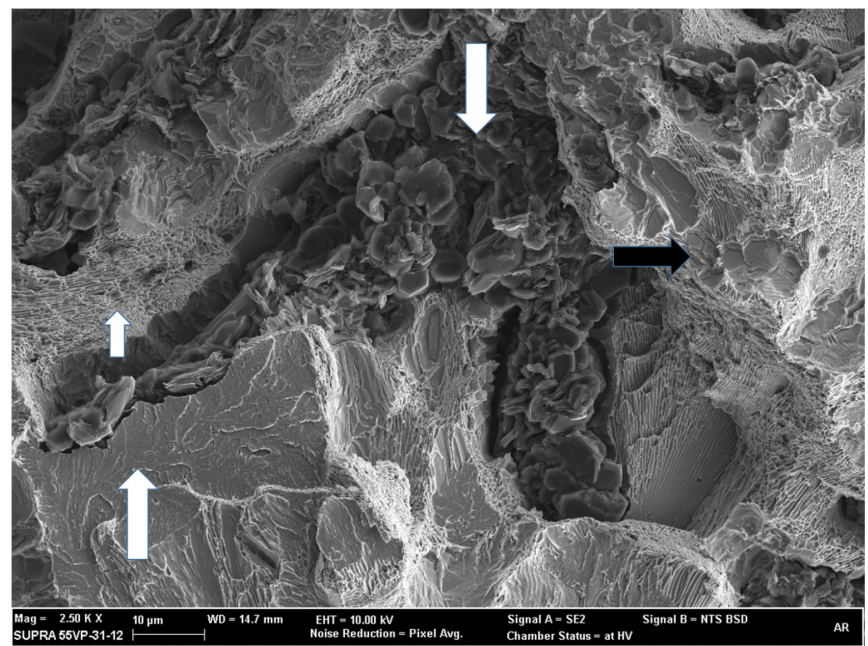

Figure 8 - Cleavage of pearlite (big white arrow, up), ductile fracture of pearlite (small white arrow, up), fracture of the graphite/matrix interface (black arrow) and fracture of graphite (white arrow, down). (CGI, $\left.200^{\circ} \mathrm{C}\right)$. 


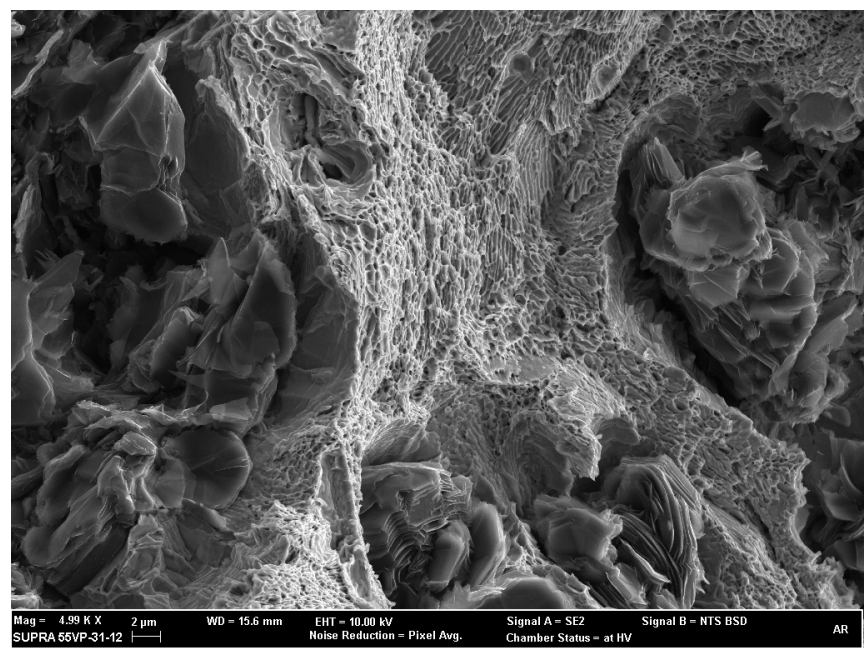

Figure 9 - Ductile fracture of pearlite, fracture of the graphite/matrix interface, with a clear separation of the graphite and the matrix. Separation of the graphite plates (CGI, $300^{\circ} \mathrm{C}$ ).

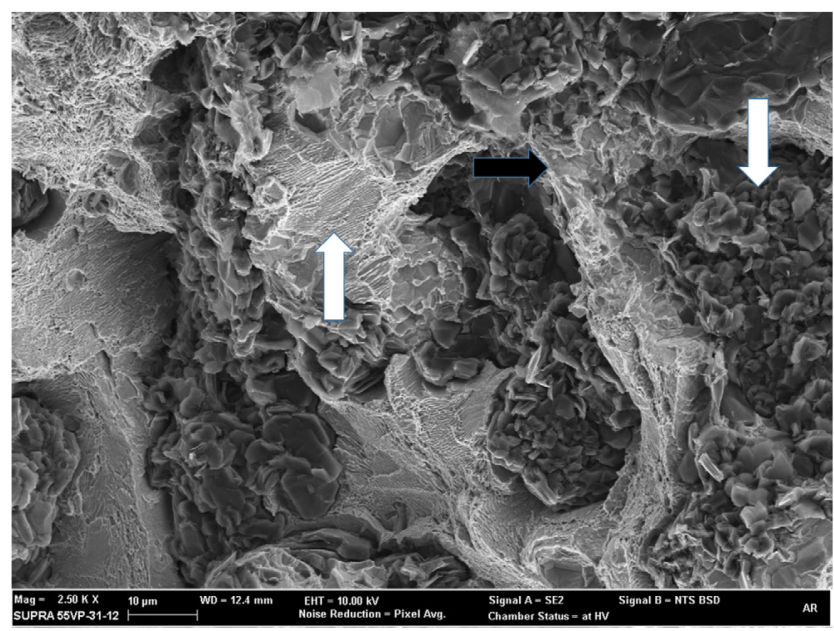

Figure 10 - Fracture of pearlite (white arrow, up), of the graphite (white arrow, down) and of the graphite/matrix interface (black arrow). (CGI, $450^{\circ} \mathrm{C}$ ).
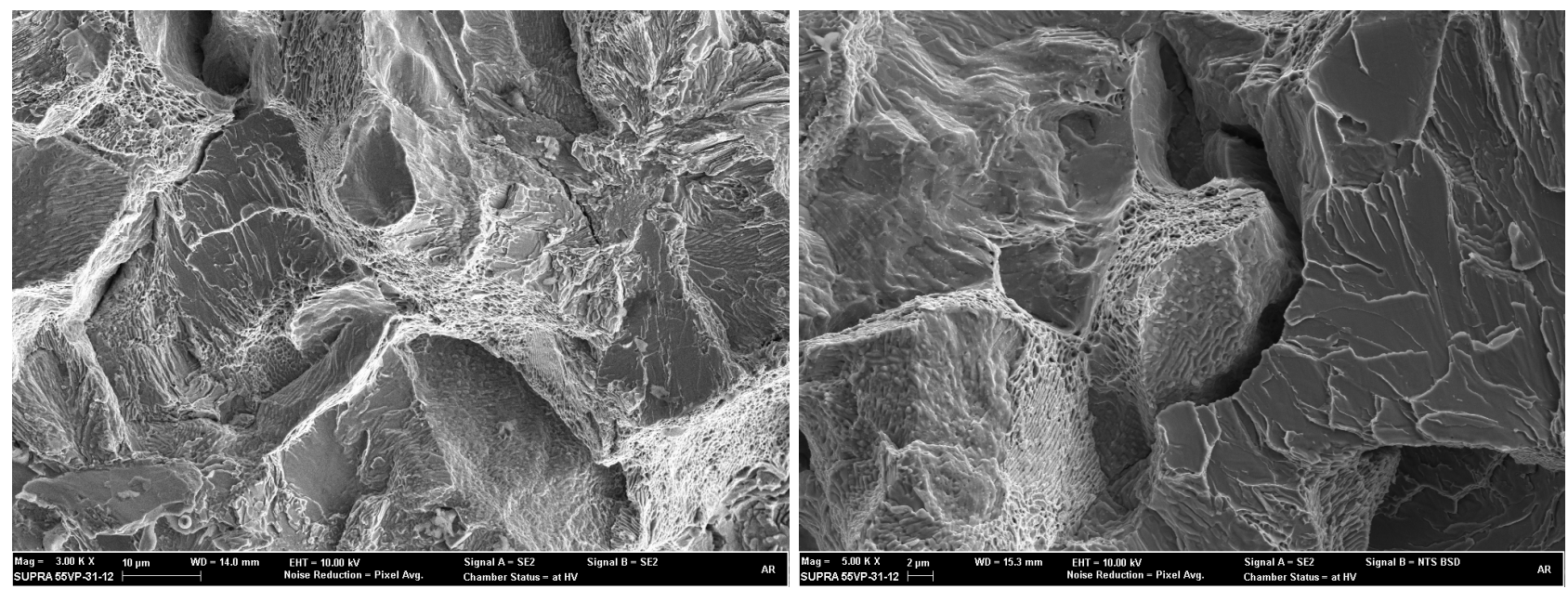

Figure 11 - Boundaries of cleavage facets showing orthogonal cracks. CGI 450 . a) $350^{\circ} \mathrm{C} \mathrm{b}$ ) $300^{\circ} \mathrm{C}$.

Figure 12 shows the results of metallographic analysis below the fracture surface. Cracks were identified, associated with the tips of graphite particles (flakes or worms), with sizes of 2 to $30 \mu \mathrm{m}$. The nucleation of cracks, from the tips of graphite particles, connected with some plastic deformation, is a mechanism of reducing the stress concentration at these locations, so that once the peak stress is relieved, the crack remains stable. Only when the stress increases, the crack can grow and lead to the fracture of the sample. The results of crack density, below the fracture surface, are 
given in Figure 13, showing that the crack density has no correlation with the test temperature, and there is no difference between the results of the gray irons. On the other hand, crack density is higher in CGI compared to gray irons, which shows the potential of CGI to withstand the presence of a large number of cracks. Similar behavior was observed in fatigue tests with these cast irons [8].

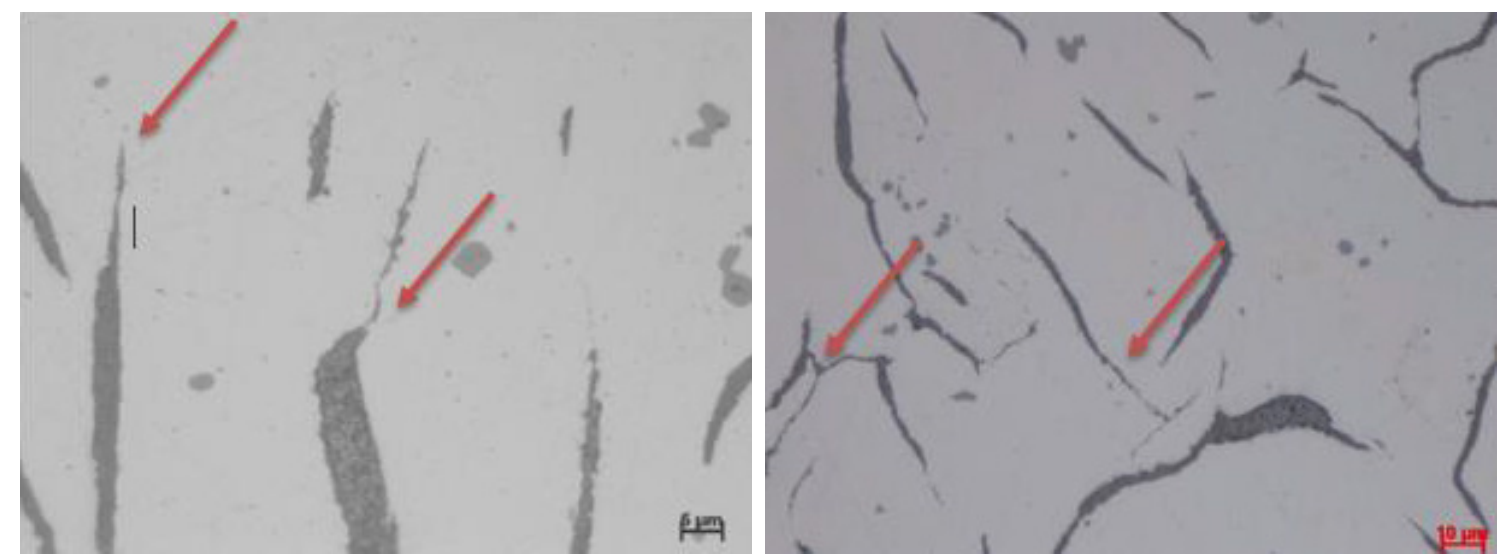

Figure 12 - Cracks below the fracture surface, associated with graphite particles. GI $300 \mathrm{Mo} .450^{\circ} \mathrm{C}$ and $500^{\circ} \mathrm{C}$.

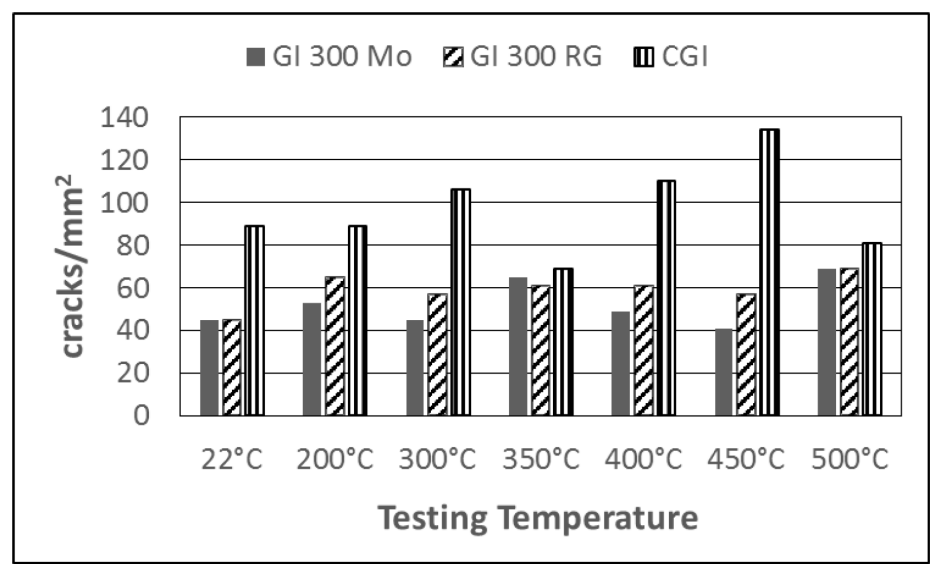

Figure 13 - Crack density below the fracture surface. All cracks are associated with graphite particles. No effect of the testing temperature. Higher amount of cracks on CGI samples.

\section{Conclusions}

The experimental results with tensile tests up to $500^{\circ} \mathrm{C}$ show that the different strengthening mechanisms, use of Mo or modification of the graphite structure, are both efficient for increasing the strength at room temperature as well as at high temperatures. The CGI has a lower strength reduction with temperature than the gray irons. At $450^{\circ} \mathrm{C}$, while gray irons present about $80 \%$ of the strength at room temperature, CGI keeps $87 \%$ of its initial strength.

Metallographic analysis below the fracture surface, in gray irons and CGI, show the presence of cracks associated with the graphite particles, with sizes of 2 to $30 \mu \mathrm{m}$. The quantity of cracks is higher in CGI than in gray irons, showing that this material displays a higher resistance to crack propagation.

The fracture surfaces of gray iron and CGI, tested at different temperatures, show great plastic deformation of the matrix. In gray irons, the preferential fracture site is the interface graphite/matrix. In CGI, the graphite/matrix interface is not a preferred site of fracture, due to the rough interface, which certainly contributes to the high resistance of this material. When graphite fracture occurs, the fracture shows the microplates of the graphite structure.

These results of high temperature tests show the enormous potential of CGI for use in cylinder heads for high-performance engines. 


\section{Acknowledgments}

The experiments reported in this paper were conducted in the partnership with Tupy and SENAI Innovation Institute for Manufacturing Systems.

\section{References}

[1] Cameron, I. 30 ${ }^{\text {th }}$ Annual Engine Technical Review. Diesel Progress Int, p. 12-36, Jun 2014.

[2] F. Wilberfors, Cast Irons for Heavy Trucks, SPCI Mar del Plata, 2014.

[3] G. N. J. Gilbert. The growth and scaling characteristics of cast irons in air and steam. BCIRA Journal, 7 (1959), 478-566.

[4] E. Nechtelberger. The properties of cast iron up to $500^{\circ} \mathrm{C}$. Technocopy Ltd, England, 1980.

[5] H. Gasparin, G. Verran, W. L. Guesser, M. Tomiyama, C. E. Junges. Propriedades mecânicas a altas temperaturas de ferros fundidos cinzentos. 69th ABM International Annual Congress. São Paulo, 2014.

[6] M. V. Martínez Charles. Envejecimiento Dinámico por Deformación em Fundiciones de Hierro Tipo CGI. Master Thesis. CINVESTAV, Saltillo, México, 2016.

[7] I. C. H. Hughes \& J. Powell. Compacted graphite irons: high-quality engineering materials in the cast iron family. BCIRA Journal, Report 1628, 1985, 262-272.

[8] W.L. Guesser, L. C. Guedes, A. L. Müller, V. B. Demetrio, A. Rabelo. A fatigue and fracture study on high strength cast irons. SPCI-XI, Jönköping, 2017. 